\title{
DOCUMENTAÇÃO
}

\section{A Geografia dos Documentos Eclesiais: o envolvimento da Igreja Católica com a questão agrária brasileira.}

Marco Antonio Mitidiero Junior ${ }^{*}$ Universidade Federal de Sergipe

\begin{abstract}
Resumo
O presente estudo tem como objetivo discutir o envolvimento da Igreja Católica na chamada questão agrária brasileira. Para isso, será dado ênfase nas raízes históricas que levaram um segmento de religiosos a atuarem em defesa do homem do campo. Essa história não pode ser descrita e nem analisada se não partir da constatação de que a atitude pioneira de alguns clérigos católicos foi iniciada com a publicação de documentos episcopais que denunciavam os resultados perversos produzidos pelo desenvolvimento do capitalismo no campo. Uma série de documentos de denúncia publicados pelos religiosos em diferentes regiões do Brasil mapearam, geograficamente, a situação social e territorial de famílias camponesas, posseiros e indígenas em todo território nacional.
\end{abstract}

Palavras-chave: documentos episcopais, desenvolvimento capitalista, defesa do homem do campo.

\section{Resumen}

El presente estudio tiene como objetivo discutir el envolvimiento de la Iglesia Católica en la dicha cuestión agraria brasileña. Para eso será dado énfasis a las raíces históricas que llevaron un segmento de religiosos a actuar en defensa del hombre del campo. Esa historia no puede ser descripta y tampoco analizada si no sale de la constatación de que la actitud pionera de algunos clérigos católicos fue iniciada con la publicación de documentos episcopales que denunciaban los resultados perversos producidos por el desarrollo del capitalismo en el campo. Una serie de documentos de denuncia publicados por los religiosos en distintas regiones de Brasil mapearon, geográficamente, la situación social y territorial de familias de campesinos, ocupantes e indígenas en todo territorio nacional.

Palabras-clave: documentos episcopales, desarrollo capitalista, defensa del hombre del campo

\section{Introdução}

Atualmente, em pleno século XXI, o Brasil é um dos raríssimos países que ainda guardam vastas extensões territoriais em estado nativo conservado. Como afirmou Martins (1986) na década de 1980, o Brasil é um dos poucos países do mundo em que a expansão capitalista ainda esta associada à expansão territorial. Essa constatação permanece válida para extensas áreas agriculturáveis ou passíveis de exploração rural do país. É claro que se deve fazer a distinção entre as áreas ociosas apoderadas pelos grandes latifúndios improdutivos, constituindo uma irracionalidade ao desenvolvimento capitalista, das áreas ainda não apoderadas efetivamente pelos proprietários de terra. Isso não quer dizer que existam vastas extensões de terra sem proprietários

\footnotetext{
Professor no Departamento de Geografia da Universidade Federal de Sergipe. Contato: mitidierousp@yahoo.com.br.
} 
portadores de títulos legais ou não da terra, mas que muitas dessas áreas nem sequer possuem limites territoriais e infraestrutura que demarque sua apropriação de fato.

Foi na raiz do processo de ocupação desses espaços, no fim dos anos 1960 e início dos anos 1970, que a lgreja passou a se posicionar frente ao desenvolvimento capitalista no campo. Os efeitos perversos dessa expansão começaram a ecoar nas Igrejas locais, ou melhor, passaram a ser fatos cotidianos e visíveis aos clérigos de diversas paróquias e dioceses do país, com destaque para a região da Amazônia Legal.

Nesse período histórico, despontou a figura de Dom Pedro Casaldáglia, bispo na prelazia de São Félix do Araguaia, no nordeste matograossensse, região da Amazônia Legal. Dom Pedro soube traduzir por meio das suas ações, de seus textos e de seus poemas a crítica situação social dos povos da Amazônia (posseiros, ribeirinhos, peões, indígenas e etc.). Mostrou que a expansão capitalista nessas áreas ao invés de representar a chegada do progresso e a modernização do território, apresentou a ganância e o desprezo das vidas humanas e da natureza como "carro chefe" de ocupação desses espaços.

A personificação do avanço capitalista representado por modernas empresas nacionais e internacionais (Bradesco, Atlântica Boa Vista, Anderson Calyton, Goodyear, Nestlé, Mitsubishi, Camargo Correa, Mappim, Volskswagem e etc.), criou na região amazônica o signo de uma região da providência, na qual, caberia ao investimento de capital externo, transformar essa região numa área prospera e moderna. Foi o que realmente não aconteceu. Essas empresas modernas, latifundiários e grileiros de terra, madeireiras, mineradoras e conglomerados de empresas patrocinaram a devastação de parte significativa da floresta amazônica. Devastação essa que extrapola a idéia de destruição do meio ambiente, da "derrubada da mata", mas que levou o fim de muitas comunidades e assassinou muitas pessoas.

A empresa capitalista, símbolo do progresso, atua, tradicionalmente, da forma mais desumana possível para a reprodução ampliada do seu capital ${ }^{1}$. No caso amazônico, o capital atuou (e atua) como vespas em busca de seu

\footnotetext{
1 Há uma imensa quantidade de estudos que denunciam esse processo perverso de ocupação da Amazônia, entre
} eles destaco as pesquisas de: Martins (1980, 1986, 1997), Oliveira (1996, 1997), Gonçalves (2003), Sader (1986). 
alimento, transformando a maior floresta tropical do mundo no palco de injustiças sociais, assassinatos, miséria e devastação que, aos olhos de Dom Pedro e de outros clérigos da região, significou a perca de humanidade naquelas experiências.

No valioso estudo de Oliveira (1997), esse pesquisador mostra claramente que a principal faceta da ocupação da região amazônica foi a usurpação e pilhagem de toda a sorte de recursos presentes nessa floresta, principalmente, da madeira, do minério, das terras e da mão-de-obra barata - dos braços quase nada onerosos ao investimento das empresas às formas de escravidão moderna. Em minha percepção, Oliveira, descreve uma das várias "veias abertas da América Latina" que jorram sangue até hoje.

O governo incentivou e patrocinou essa corrida voraz pelo solo e subsolo amazônico, todos que se antepunham à frente desse movimento eram sumariamente retirados de cena. E, "as vítimas dessa apropriação induzida, foram, antes de tudo, os povos indígenas".

Logo as formas de organização das nações indígenas que sempre encantou parte do pensamento católico, em virtude delas se organizarem comunitariamente no território. Viam-na como um exemplo perfeito da harmonia do homem com a natureza, embora muitos povos guerreassem entre si ou possuíssem práticas culturais que chocavam a sociedade como um todo. De qualquer maneira, a pilhagem e os saques dos territórios indígenas associados a massacres e genocídios foi uma constante no "progresso" dessa área. Em várias paróquias, os clérigos constantemente tomavam conhecimento sobre o processo violento que recaia sobre as tribos indígenas. $\mathrm{Na}$ interpretação de Almeida (1991), a violência na Amazônia:

\footnotetext{
"Não deriva de impulsos irracionais, como as vezes pode deixar transparecer as sucessivas chacinas e os casos de massacres em que indígenas e famílias de camponeses são dizimados, mas de artifícios urdidos, convenientemente delineados e refletidos, constituindo-se, não raro, em estratagemas próprios de um intenso processo de concentração fundiária"”.
}

$\mathrm{Na}$ ocular da Igreja da Amazônia todo esse processo mostrava a desumanização dos espaços onde o progresso chegava. Portanto, viam nos

\footnotetext{
${ }^{2}$ Apud Macedo, 2001, p. 19.
} 
atos desumanos das empresas e de fazendeiros a negação completa dos desígnios de Deus.

Somado as políticas públicas de incentivo ao investimento de capital, os projetos de colonização também demonstraram a trágica face do desenvolvimento capitalista brasileiro. Principalmente os colonos expulsos de suas terras no Sul do país migraram para a região amazônica impulsionados pelos projetos governamentais. Ao chegaram lá, encontraram a falta de infraestrutura e os empecilhos que a floresta oferecia (clima demasiadamente unido e chuvoso, terras fracas, endemias tropicais, animais perigosos e etc.). Além disso, muitos desses migrantes eram postos frente a frente com povos indígenas e grupos de posseiros, o que muitas vezes levou a estabelecer conflitos entre esses sujeitos. Ou seja, enquanto as grandes empresas usurpavam solo e subsolo amazônico, grupos sociais pobres e oprimidos brigavam por pequenas glebas de terra.

Os colonos que não suportaram as limitações apresentadas pela floresta e os conflitos que brotavam da terra, retornaram aos seus Estados de origem, constituindo a faísca inicial para a formação dos movimentos de sem terra ${ }^{3}$.

Todo esse cenário de destruição, conflitos, miséria e sofrimento exigiu que as Igrejas locais tomassem algum tipo de postura ao assistir os infortúnios que a chegada do capital modernizador causava. Inspirado pela Teologia da Libertação, nasceu das mãos de Dom Pedro Casaldáglia uma carta pastoral que denunciava o processo de pilhagem dos recursos naturais da Amazônia e a opressão que vitimava o povo pobre amazônida. O texto dessa carta, intitulada de "Uma Igreja da Amazônia em Conflito com o Latifúndio e a Marginalização Social", foi o ponta pé inicial para a reformulação do tratamento (missão) das Igrejas locais para com os seus fiéis.

Depois da divulgação dessa carta em 10 de outubro de 1971, que fez eco interna e externamente a Igreja, outros documentos com o mesmo caráter

\footnotetext{
3 Foi justamente esse o processo de formação do Movimento dos Trabalhadores Rurais Sem Terra (MST). Os colonos gaúchos que iam perdendo suas terras para os bancos e para grandes fazendeiros, ocuparam áreas do Rio Grande do Sul designadas aos índios Kaiagang, o que colocou em confronto direto dois grupos sociais marcadamente oprimidos na sociedade brasileira: índios e camponeses. Eram índios e camponeses lutando pelo mesmo espaço. A solução proposta pelo governo foi fornecer terras para essas famílias nas fronteiras da Amazônia brasileira, mas como ao chegar nessa região não havia possibilidades infraestruturais fornecidas pela administração pública, muitos desses colonos retornaram e se uniram para lutar pela terra em seu próprio Estado. Essas lutas foram organizadas e incentivadas por quadros da CPT nos anos de 1978 e 1979, constituindo o germe de formação do MST.
} 
começaram a aparecer em diferentes regiões brasileiras. Dos bispos do Nordeste surgiu o texto "Ouvi os Clamores do Meu Povo" em 1973. No mesmo ano, foi publicado o documento de urgência "Y-Juca Pirama - o Índio: aquele que deve morrer", por bispos e missionários da Amazônia. Do Centro-oeste do país os bispos publicaram o texto "Marginalização de um Povo, o Grito das Igrejas” em 1974. Em 1980, num documento de caráter mais institucional do que esses primeiros, por ter sido publicado pela CNBB, "Igreja e os Problemas da Terra", analisa e denuncia os resultados do desenvolvimento capitalista no campo brasileiro.

Na concepção de Morais (1982), esses textos são os documentos mais ousados e importantes de toda a vida da lgreja católica brasileira. Segundo Lowy (2000, p. 145), "esses documentos foram, na verdade, as declarações mais radicais jamais publicadas por um grupo de bispos em qualquer parte do mundo..." O brasilianista Scott Mamwaring ${ }^{4}$ afirma que esses documentos eram provavelmente as declarações mais progressistas já emitidas por um grupo de bispos em todo o mundo.

É interessante observar o valor político dado a uma carta pastoral, muito maior, por exemplo, do que qualquer livro ou artigo acadêmico que explicitasse e denunciasse os problemas do Brasil rural. Ser uma espécie de documento assinada por um bispo ou por um grupo de bispos, na maior nação católica do mundo, certamente teve um peso na recepção dessas cartas pelas diversas instituições desse país e pela sociedade ${ }^{5}$.

\section{Uma Igreja da Amazônia em Conflito com o Latifúndio e a Marginalização Social}

Essa carta pastoral divulgada no dia 10 de outubro de 1971 e publicada em 23 de outubro do mesmo ano, exatamente no dia da ordenação episcopal de Dom Pedro Casaldáglia como bispo da prelazia de São Félix do Araguaia,

\footnotetext{
4 Ver Pessoa (1999, p. 78)

${ }^{5}$ A carta pastoral de Dom Inocêncio Engelke, "Conosco, Sem Nós ou Contra Nós se Fará a Reforma Agrária", publicada em setembro de 1950, é considerada o primeiro do envolvimento da Igreja Católica na questão agrária brasileira. Porém, era um documento anticomunista, que não questionava a propriedade privada da terra e apenas mostrava a situação de miséria dos camponeses. Mesmo assim, mesmo não tem um valor profético e de denúncia como as cartas publicadas na década de 1970, o documento de Dom Inocêncio significou um marco na atuação da Igreja diante das questões rurais.
} 
foi o primeiro grito dos clérigos libertadores para a salvação do homem do campo e dos indígenas.

"Depois de três anos de missão neste norte do Mato Grosso, tentando descobrir os sinais do tempo e do lugar, juntamente com outros sacerdotes, religiosos e leigos, na palavra, no silêncio, na dor e na vida do povo, agora, com motivo da minha sagração episcopal, sinto-me na necessidade e no dever de compartilhar publicamente, como que a nível Igreja nacional e em termos de consciência pública, a descoberta angustiosa, premente (...) Se "a primeira missão do bispo é a de ser profeta e o profeta é aquele que não tem voz daqueles que não tem voz (card, Marty), eu não poderia, honestamente, ficar de boca calada ao receber a plenitude do serviço sacerdotal" (p. 1) ${ }^{6}$.

Como é uma carta pastoral escrita em primeira pessoa pelo bispo da prelazia, a princípio pode parecer um desabafo personalizado dos fatos observados por Dom Pedro. Mas, em contrapartida, esse texto assinado por um só bispo, foi a junção dos sentimentos de vários estratos sociais, inclusive de parte dos clérigos, a respeito do progresso perverso das forças produtivas. Nessa perspectiva, a referida carta serviu de inspiração para outros religiosos e instituições, e exigiu do mundo acadêmico e político respostas ao drama social dos camponeses e índios amazônidas.

Na interpretação de Poletto (1997, p. 31):

\begin{abstract}
"Mais do que um documento, este texto expressava a reflexão e a fundamentação política e teológica de uma prática pastoral já em andamento. A oportunidade, a sagração episcopal de D. Pedro, servia de celebração do compromisso de toda a equipe da Prelazia". Processos pastorais semelhantes estavam sendo vivenciados por outras igrejas locais, e não apenas na Amazônia. Mas foi uma iniciativa de igrejas dessa região que deu origem à Comissão Pastoral da Terra".
\end{abstract}

$\mathrm{Na}$ interpretação datada de José de Souza Martins (1997), ele reconhece o papel da carta pastoral vinda da prelazia de São Félix do Araguaia:

\begin{abstract}
"Pela primeira vez, na história do Brasil, em um documento público se afirma, se dá uma visão de conjunto, de totalidade, do lado perverso funcionamento do capital. Este documento é um marco, não só na história da Igreja, mas é um marco na história social e política do país. Não por acaso, ele atraiu sobre a Igreja de São Félix do Araguaia todas as iras possíveis dos representantes dessa extrema e tremenda devastação".
\end{abstract}

\footnotetext{
6 Casaldáglia, Dom Pedro - "Uma Igreja da Amazônia em conflito com o latifúndio e a marginalização social". São Feliz do Araguaia, 1971, www.prelaziadesaofelizdoaraguaia.org.br, acesso em 30/11/2005.
} 
A atitude de Dom Pedro desafiou o conjunto das Igrejas a dar respostas ao que vinha acontecendo com o seu povo, com isso o grupo que pensou a formação do Conselho Indigenista Missionário (CIMI) e a Comissão Pastoral da Terra (CPT) consideram esse texto o germe eclesial/pastoral para a organização desses órgãos. Foi uma Igreja que tomou partido e publicizou uma experiência concreta vivida naquele período histórico, período que Dom Pedro chamou de "momento publicitário" dos projetos e realizações nefastas na Amazônia Legal.

A estrutura da carta pastoral assemelha-se a elaboração de monografias geográficas. Dom Pedro descreve primeiro a situação geográfica da prelazia de São Félix, em seguida a história de formação dos povoados, para depois radiografar e analisar a situação social e pastoral desse município e dos povoados vizinhos.

O reordenamento territorial da área da prelazia patrocinado pelos projetos governamentais e efetivado pelos empresários, também "quase sempre sulistas", cunhou uma nova forma de gestão territorial muito mais perversa do que as formas anteriores. Pois, o apoderamento das terras pelos sulistas, significou, além do fim de terras livres para os posseiros e índios, a expropriação das terras desses dois sujeitos sociais; e, a administração pública municipal atrelou-se diretamente aos interesses dessas novas figuras sociais. Esses fatos causaram uma situação social dramática na região, descrita fielmente por Dom Pedro. As características sociais, econômicas, políticas e territoriais da prelazia, o que ele chamou de "panorama sócio-pastoral", estão marcadas pelas seguintes transformações:

- a territorialização do capital materializado no aumento voraz dos latifúndios ${ }^{7}$;

- o poder e a política local historicamente concentrada nas mãos dos coronéis se fundiram aos desígnios dos novos empresários. Além de fraudes eleitorais e roubo deliberado de dinheiro público, agora cabia ao governo municipal eliminar tudo que poderia constituir um

\footnotetext{
7 Segundo a carta pastoral, "as terras todas compradas - ou requeridas - ao Governo do Estado do Mato Grosso por pessoas interessadas, não os moradores, a preço irrisório, foram depois vendidas a grandes comerciantes de terras, que posteriormente a vendem a outros. Abelardo Vilela e Ariosto da Riva, são dois comerciantes tidos como os desbravadores da Amazônia que, segundo afirmações suas, já venderam mais de um milhão de alqueires".
} 
empecilho ao capital vindo de fora, com isso a polícia local teve importante papel na opressão ao povo pobre da prelazia;

- a divisão territorial da administração pública era composta por municípios com áreas imensas dificultando qualquer rara iniciativa de assistência social básica para a população ${ }^{8}$ : a higiene pública não existia, hospitais e escolas eram poucas e funcionavam em condições calamitosas, não existia política habitacional, sendo que a maior parte da população da prelazia viviam em barracos, não havia 0 fornecimento de água encanada, não há coleta de lixo, não havia serviço normal de correio, o transporte publico era incipiente e precário (inclusive os aviões da Vasp) e etc.;

- os posseiros, "quase todos" camponeses nordestinos, verdadeiros desbravadores da região, passaram a ser expulsos, quando não assassinados, pela invasão dos fazendeiros e das modernas empresas;

- as nações indígenas Xavante e Tapirapé estavam sendo sumariamente expulsas de seus territórios e suas terras invadidas por fazendeiros $^{9}$. Era o que acontecia no famoso Parque Nacional do Xingu, onde exatamente a metade de sua área estava dentro da prelazia de São Félix. Com a construção da BR-80 que cortava esse parque significou a chegada dos invasores e o (re)início do processo de expulsão e extermínio dos índios;

- com a chegada dos investimentos externos a necessidade de mão-deobra aumentou, o processo de formação dessa mão-de-obra na região ajudou a criar uma figura social chamada de "peão", denominando aquele trabalhador arrebanhado mas periferias das grandes cidades, principalmente do Norte e Nordeste, que ao chegar na fazenda onde vai trabalhar já estava preso por laços de dívidas e favores ao

\footnotetext{
8 "Há extensão dos municípios já é uma estrutura de desequilíbrio social. A distância da sede do município traz consigo o máximo de desinteresse e esquecimento por parte das autoridades, a impossibilidade de recurso e protesto por parte do povo (Barra do Garça esta a quase $700 \mathrm{Km}$ de São Félix (...) Há um só juiz em toda a região (...) A polícia local, freqüentemente mandada para cá de castigo, vendem-se com extrema facilidade aos poderes do comércio e dos fazendeiros..."

9 "Se a problemática causada pelo latifúndio com relação ao posseiro é grave, não menos greve foi a situação criada para os índios e suas terras".
} 
empreiteiro e ao patrão, constituindo assim a chamada "escravidão branca";

- alguns pontos gerais que caracterizavam a sociabilidade do povo pobre da prelazia eram: a alienação política, extrema passividade em relação aos aparelhos opressores, obediência e resignação, forte religiosidade popular, devoção católica e evangélica que contribuíam com a passividade social, racismo e submissão das mulheres, e baixíssima escolaridade;

- além do povo pobre morador dos municípios e povoados, dos camponeses e índios, compunham a sociedade da prelazia de São Félix os pequenos coronéis e comerciantes locais, e os novos empresários sulistas e seus empregados, funcionários públicos e os clérigos (bispo e padres que eram todos estrangeiros).

Toda essa paisagem trágica exigiu um "grito desta Igreja" local que começou a fazer barulho após a publicação da carta pastoral. Na concepção elementar de Dom Pedro era preciso agir, por isso, em todo o texto e como fundamentação das suas atitudes pastorais, esse bispo, como se pode ler na carta, acatava fielmente as deliberações vindas da Conferência de Medellín: “Não basta refletir, obter mais clareza e falar. É preciso agir. Esta não deixou de ser a hora da palavra, mas tornou-se, com dramática urgência, a hora da ação". Com essa carta, inaugurou um longo período de ações concretas (territoriais) da lgreja brasileira.

\section{Y-Juca Pirama, o Índio: Aquele que deve morrer. Documento de urgência de bispos e missionários}

No dia 25 de dezembro de 1973, dia do vigésimo aniversário da Declaração Universal dos Direitos Humanos, um grupo (não-grupo) de bispos e padres publicaram o referido texto de urgência denunciando o extremo descaso público com as populações indígenas de nossa nação ${ }^{10}$.

10 Os clérigos que assinaram esse documento são: Dom Maximo Biennès (bispo de Cáceres - MT), Dom Hélio Campos (bispo de Viana - MA), Dom Estevão Cardoso de Avelar (bispo de Marabá - PA), Dom Pedro Casaldáglia (bispo de São Félix - MT), Dom Tomás Balduíno (bispo de Goiás - GO), Dom Agostinho José Sartori (bispo de Palmas - PR), Frei Gil Gomes Leitão (missionário de Marabá - PA), Frei Domingos Maia Leite (missionário de 
"Os Bispos da região Extremo Oeste declaram: Assistimos em todo o país à invasão e gradativo esbulho das terras dos índios. Praticamente não são reconhecidos os seus direitos humanos, o que os leva paulatinamente à morte cultural e também biológica, como já sucedeu a muitas tribos brasileiras" (p. 1).

O documento como um todo, atentava para uma trágica profecia feita por Marechal Rondon em 1916: "Mais tarde ou mais cedo, conforme Ihes soprar o vento dos interesses pessoais, esses proprietários - coram deum soboles (ante a face de Deus) - expelirão dali os índios que, por uma inversão monstruosa dos fatos, da razão e da moral, serão considerados e tratados como se fossem eles os intrusos, salteadores e ladrões" (p. 8). E foi o que justamente aconteceu. O desenvolvimento do capitalismo no campo brasileiro revitalizou o processo de extermínio dos indígenas iniciado com a colonização portuguesa, tanto que os empresários sulistas ficaram conhecidos como "novos bandeirantes", o que, em minha opinião, faz alusão a trajetória de extermínio das populações locais e não à noção de desbravadores que a historiografia oficial insiste em fortalecer.

Esses novos bandeirantes, portadores da modernidade que chegava tardiamente a diversas localidades brasileiras, anunciaram que os povos indígenas e economias comunitárias estavam fadas ao desaparecimento por não proporcionarem nenhum tipo de avanço social e econômico. Mais grave ainda é que essa ideologia estava inteiramente presente nas políticas públicas propostas pelos militares.

No pensamento dos clérigos era justamente as peculiaridades da formação social, econômica, política e cultural dos indígenas a riqueza a ser preservada e difundida. $\mathrm{O}$ documento $\mathrm{Y}$-Juca-Pirama ressaltou que o modo de vida indígena estava e está em profunda consonância com muitos dos preceitos bíblicos, e que o desenvolvimento do capitalismo no campo negava integralmente esses preceitos.

A Igreja Libertadora considerou como "valores" as características essenciais da organização social indígena. É importante exaltar alguns desses 
valores que ajudaram a formar as concepções sobre agricultura, reforma agrária e organização social no campo da Igreja:

- o sistema de posse e uso da terra indígena é comunitário, inexistindo a propriedade privada e individual sobre a terra. Os religiosos vêem nele a realização dos preceitos bíblicos presentes tanto no Velho como no Novo Testamento;

- a produção e a distribuição dos frutos do trabalho são feitas de forma igualitária para suprir as necessidades de cada um dos componentes do grupo, com isso o índio nunca se preocuparia com a comercialização dos produtos visando incessantemente a busca do lucro;

- a organização social esta baseada na coletividade e não na individualização dos direitos. Assim, a organização do poder, embora comporte a figura do chefe (Cacique e Pajé), é compartilhada ${ }^{11}$;

- o processo de formação educacional do índio caracteriza-se pelo exercício da liberdade ${ }^{12}$;

- $\quad$ as sociedades indígenas vivem em harmonia com a natureza ${ }^{13}$.

\section{"Eu Ouvi os Clamores do Meu Povo"}

Embora esse documento tenha um caráter mais generalista, com 0 objetivo de analisar e de denunciar a situação econômica, social e política de uma região brasileira, o campo e seus antigos problemas foram privilegiados no argumento dos bispos nordestinos. "Eu Ouvi os Clamores do Meu Povo" "14, publicado em 6 de maio de 1973, reuniu bispos de vários estados da região Nordeste, na redação de uma carta pastoral que denunciasse a situação de opressão é miséria do povo nordestino ${ }^{15}$.

\footnotetext{
11 "Assim o chefe não é aquele que manda, mas sim o sábio que aconselha o que deve ser feito. Se os índios seguem ou não seus conselhos, o problema não é do chefe. Ele é apenas um líder que aconselha, não um patrão que determina..." (p. 13).

12 "Aprendem a ser livres desde a infância (...) pois um pai nunca obriga o filho a fazer o que ele não quer" (p. 13).

13 "Francisco Meireles sonha: Intimamente gostaria que eles pudessem ser mantidos em suas aldeias e que nós civilizados, ao invés de incutir-lhes nossos padrões culturais, aprendêssemos com os índios que sempre vivem em harmonia não só com o grupo mas com a própria natureza" (p. 13).

14 Documento publicado pelos bispos e superiores religiosos no Nordeste brasileiro em consonância com as conclusões e apelos da XIII Assembléia Geral da CNBB.

15 Os bispos que assinaram esse documento foram: 0 arcebispo de Olinda e Recife Dom Hélder Câmara, o bispo titular de Fussala e auxiliar de Olinda e Recife Dom José Lamartine Soares, o bispo de Pesqueira (PE) Dom Severino Mariano Aguiar, o bispo de Afogados da Ingazeira (PE) Dom Francisco Austregésilo Mesquita, o arcebispo
} 
O documento inicia-se com uma epígrafe bem sugestiva - "Eu vi a aflição do meu povo e ouvi os seus clamores por causa dos seus opressores. Sim: eu conheço seus sofrimentos (Êx. 111,7)" - e toda a sua estrutura estará fundamentada a partir de um discurso religioso influenciado pelas interpretações teológicas da Teologia da Libertação. O texto é dividido em introdução, a descrição da realidade nordestina, as raízes históricas dessa região e sua relação com a situação social daquela época, a análise das concepções de desenvolvimento regional, o problema agrário e conclusão. É importante ressaltar e analisar alguns pontos desse texto escrito pelo bispado nordestino:

1) O caráter teológico libertador: a carta prima pela interpretação do Evangelho a partir do tempo presente, exigindo a ação em busca de transformações sociais ("Somos, pois, movidos a falar pela Palavra de Deus, que julga os acontecimentos históricos. E é nesta luz que procuramos interpretar os gemidos do povo, os fatos e acontecimentos de cada dia (...) não se poderá restringir a palavra a mero efeito retórico").

2) A utilização dos dados da ciência e dos órgãos governamentais: a radiografia feita sobre a situação social (renda per capita, trabalho, alimentação, fome, habitação, educação e saúde) do povo nordestino esta calcada na análise de dados de pesquisas realizadas tanto por universidades como por institutos do governo federal.

3) A critica direta a histórica atuação da Igreja: é sintomático o caráter aberto e de revolta desse documento frente à posição da Igreja hierárquica, pois, sem rodeios, ataca essa instituição ("A Igreja, por sua vez, não raro, vem se ombreando com os detentores da dominação cultural, social, política. Muitas vezes ela se tem identificado mais com os dominadores do que com os dominados. Sua configuração piramidal fazia com que seus ministros falassem alto dos púlpitos para um povo que os escutava passivamente. A Igreja, dentro da cultura dominante, tornou-se, então, assistencialista, atrasando, consequentemente, por vezes, a marcha do Povo para se libertar".)

de São Luiz do Maranhão Dom João José da Motta e Albuquerque, o bispo auxiliar de São Luiz do Maranhão Dom Manoel Edmilsom da Cruz, o bispo auxiliar de S. Antôno das Balsas (MA) Dom Rino Carlesi, o bispo de Bacabal (MA) Dom Pascásio Rettler, o bispo de Viana (MA) Dom Francisco Hélio Campo, o bispo de Crateús (CE) Dom Antonio Batista Fragoso, o arcebispo de João Pessoa (PB) Dom José Maria Pires, o bispo de Campina Grande (PB) Dom Manoel Pereira da Costa e o bispo de Própria (SE) Dom José Brandão de Castro. 
4) A raiz histórica da formação sócio-territorial nordestina: nesse ponto ressaltam a permanência colonial da organização do trabalho no campo, colocando a servidão e situações assemelhadas a escravidão como formas atuais das relações trabalhistas.

5) A análise regional: o texto apresenta uma discussão, iniciada na década de 1950, muito presente no contexto político (e acadêmico) brasileiro na data de publicação da carta, que é o tema do planejamento regional. Contextualiza a expectativa da Igreja com a redução das disparidades regionais a partir das políticas públicas, mas anuncia decepção ao constatarem que o planejamento regional no Nordeste resultou em maiores desigualdades sociais entre seu povo.

6) A analise da situação política e econômica brasileira (nacional e internacional): pontuam que a ditadura militar e o milagre econômico significaram "ausência de liberdade, a violência da repressão, o empobrecimento do povo e a alienação dos interesses nacionais ao capital estrangeiro".

7) A apresentação do "problema agrário": após descrever os contextos políticos, sociais e econômicos do Nordeste e do Brasil, os argumentos dos bispos centram na constatação de que "no campo, tal situação adquire ainda conotações muito mais trágicas...", e analisam a estrutura fundiária e o que decorre a partir dela ("A ociosidade das terras, de um lado, e a impossibilidade de trabalhar a terra, de outro, tem como resultado os estados de subnutrição e fome que assola a população camponesa").

Com essas interpretações e constatações presentes, claramente, no documento analisado, penso que o forte teor de denúncia em direção a Igreja, ao Estado e ao modo de produção capitalista faz dessa carta outro marco na postura da Igreja brasileira.

\section{Marginalização de Um Povo. Grito das Igrejas}

Dos bispos da região Centro-Oeste é apresentado outro documento eclesial nos mesmos moldes dos documentos analisados até agora: um texto de denúncia; analítico frente realidade social, econômica e política brasileira; ao mesmo tempo centrado num recorte regional; e com teor profético. 
"Marginalização de Um Povo. Grito das Igrejas"16", publicado em 6 de maio de 1973, reuniu dois bispos (Dom Pedro Casaldáglia e Dom Tomás Balduíno) que tiveram importância preponderante nas transformações ocorridas em parte da Igreja brasileira e na formação do Conselho Indigenista Missionário (CIMI) e da Comissão Pastoral da Terra $(\mathrm{CPT})^{17}$. Tal documento serviu como substrato para as ações de várias paróquias da região Centro-Oeste na defesa dos trabalhadores rurais e camponeses.

No que condiz a particularidade dessa carta, pode-se encontrar uma linguagem diferente das outras cartas devido sua linguagem popular e, principalmente, pela coloquialidade na explicação dos processos que levam a "marginalização de um povo"; e a atenção dada a luta pela efetivação dos direitos alcançados pela população rural. Outro ponto distinto é a clara condenação do modo de produção capitalista como o causador dos males às sociedades, não obstante a essa constatação, os bispos proclamam o fim da propriedade privada de qualquer meio de produção e condenam a sociedade dividida em classes.

Já para Pessoa (1999, p. 78), "a novidade e a importância do documento do Centro-Oeste estão, principalmente, em três fatores: linguagem popular e não episcopal; utilização de dados sócio-econômicos; e denúncia do sistema capitalista como fonte de todos os males que assolam a vida do povo".

O homem do campo é o que dá substrato a noção de "marginalização" proposta no texto. Consequentemente realizam uma análise mais acurada sobre a questão da reforma agrária nesse país. Falam da não efetivação dos direitos dos trabalhadores rurais presentes no Estatuto do Trabalhador Rural, do caráter assistencialista e pouco combativo dos sindicatos rurais, descrevem as perversas relações de trabalho no campo, comentam a política agrícola do governo e escancaram a estrutura fundiária brasileira.

Por fim, vale ressaltar que essa carta pastoral é datada e referia-se ao início do processo que expansão do capitalismo na região Centro-Oeste. Passados quase 35 anos de publicação desse documento e do início de uma

\footnotetext{
${ }^{16}$ Assinaram o documento: 0 arcebispo de Goiânia Dom Fernando, o bispo de Anápolis Dom Epaminondas, o bispo de Goiás Dom Tomás, o bispo de São Felix do Araguaia Dom Pedro, o bispo de Marabá Dom Estevão e o bispo auxiliar de Porto Nacional Dom Celso.

${ }_{17}$ As atitudes tomadas por Dom Tomás e Dom Pedro certamente vieram a partir da análise da realidade na qual estavam envolvidos. Segundo Pessoa (1999, p. 80), "os dois, como bispos recém nomeados, assumiram circuscrições eclesiásticas essencialmente rurais, num momento em que extremavam os conflitos no campo".
} 
série de ações impulsionadas pela Igreja em defesa dos camponeses e indígenas, Dom Pedro, Dom Tomás e tantos outros bispos e religiosos continuam a luta, cada vez mais de resistência, em prol do homem do campo. No entanto, o contexto econômico e territorial da região é outro. A região é objeto da expansão do dito capitalismo moderno no campo, posicionando-se como um dos grandes celeiros de grãos do planeta. Essa expansão avassaladora do capitalismo no campo dessa região, muito bem caracterizada por Oliveira (2003) como o lócus da "barbárie e da modernidade", resulta na degradação ambiental de grande parte do cerrado e de parte da floresta amazônica, e na expulsão e assassinato de muitos camponeses. Segundo Gonçalves (2003), é nessa região de agricultura moderna que, em números relativos, houve a maior quantidade de assassinatos de trabalhadores rurais no ano de 2003.

\section{Considerações Finais: "Igreja e os Problemas da Terra"}

O documento "Igreja e os Problemas da Terra" congrega e aglutina os escritos e as ações que vinham sendo desenvolvidas por parte da lgreja a partir da década de 1970. Aprovado e divulgado na 18ำ Assembléia da Conferência Nacional dos Bispos do Brasil (CNBB) na cidade de Itaici (SP), no dia 14 de fevereiro de 1980, é, dentre os outros documentos analisados, o mais institucional dos textos que objetivaram analisar os problemas no campo brasileiro e a postura da Igreja diante essa perversa realidade. Ou seja, esse texto não era mais produto da reunião de um "grupo-não-grupo" de bispos envolvidos, nas suas Igrejas locais, com a luta indígena e camponesa. Agora era uma instituição que congregava todos os bispos brasileiros que assinava e publicava em conjunto um documento de repúdio a situação social nas áreas rurais desse país.

Penso que a potencia desse documento ou a sua clara definição de condenação de um sistema econômico injusto venha de duas posições assumidas pelos bispos: a) a utilização das ciências humanas na análise da questão agrária, tanto que esse texto baseou-se diretamente em um estudo do professor José de Souza Martins, intitulado de "Terra de Negócio e Terra de 
Trabalho - contribuição para o estudo da questão agrária no Brasil" ${ }^{18}$; b) e no aprofundamento teológico que deu substrato religioso e doutrinal a defesa da reforma agrária e da justiça social no campo, por isso, na fundamentação teológica do texto, seus redatores avisava que procuraram não cair no simplismo de tirar conclusões infundadas a partir de transposições meramente literais do texto bíblico, e sim captar o espírito que anima o projeto comunitário/religioso, principalmente a partir das experiências de Jesus Cristo.

$\mathrm{Na}$ "fundamentação doutrinal", foi proposto analisar a situação sócioterritorial a partir dos preceitos bíblicos, consubstanciada pelas análises científicas - principalmente sociológica - das relações sociais de apropriação das terras e de produção no campo brasileiro. Foi nesse ponto que a partir de uma distinção conceitual (acadêmica) entre "terra de exploração" e "terra de trabalho" acabou resgatando na "doutrina social da lgreja a precedência do trabalho em relação ao lucro especulativo e rentista na definição dos direitos dos camponeses" ${ }^{19}$. Essa distinção conceitual está explicada no documento:

\footnotetext{
"Terra de exploração é a terra de que o capital se apropria para crescer continuamente, para gerar sempre novos e crescentes lucros. O lucro pode vir tanto da exploração do trabalho daqueles que perderam a terra e seus instrumentos de trabalho, ou que nunca tiveram acesso a eles, quanto da especulação, que permite 0 enriquecimento de alguns à custa de toda a sociedade."

"Terra de trabalho é a terra possuída por quem nela trabalha. Não é terra para explorar os outros nem para especular. Em nosso país, a concepção de terra de trabalho aparece fortemente no direito popular de propriedade familiar, tribal, comunitária e no de posse" (p. 9).
}

Com isso, conclui-se que as cartas pastorais publicadas naquele período histórico contribuíram, em um só tempo, na produção de conhecimento sobre o tema e nas ações decorrentes da formação de instituições, movimentos sociais e organizações de luta pela reforma agrária e justiça social no campo. Tal afirmação visa elucidar que parte da Igreja Católica, com o caráter de instituição que lhe é próprio, toma partido na denuncia e reflexão sobre os problemas da terra. Ao explicitar uma posição crítica sobre o tema, fora do âmbito acadêmico e fora do âmbito governamental, fez com que a lgreja, até certo sentido, antecipasse naquele momento histórico toda produção de

\footnotetext{
${ }^{18}$ Martins, José S. - Terra de Negócio e Terra de Trabalho - contribuição para o estudo da questão agrária no Brasil. São Paulo: Cadernos CEAS, nº 67, 1980.

${ }^{19}$ Martins, 1999, p 165.
} 
conhecimento crítico das ciências humanas e a reflexão sobre políticas públicas referentes aos conflitos do campo; ainda, o discurso religioso, impregnado nos documentos de denúncia e na atuação dos clérigos, serviu como substrato a formação dos movimentos sociais, a exemplo do processo de formação do Movimento dos Trabalhadores Rurais Sem Terra (MST) entre os anos de 1978 e 1985.

\section{Bibliografia}

1. GOLÇALVES, CARLOS W. P. - Geografando nos Varadouros do Mundo. Da Territorialidade Seringalista (o seringal) à territorialidade seringueira (a reserva extrativista). Brasília: IBAMA, série educação ambiental, 2003.

2. LÖWY, MICHEL - A Guerra dos Deuses. Religião e política na América latina. Petrópolis: Vozes/CLACSO/LPP, 2000.

3. MARTINS, JOSÉ SOUZA - Expropriação e violência: a questão política no campo. São Paulo: Hucitec, 1980.

4. - A Igreja face a política agrária do Estado. In: Igreja e Questão Agrária, Paiva, V (org.), Ed. Loyola, São Paulo, 1986.

5. - O significado da criação da Comissão Pastoral da Terra na história social e contemporânea do Brasil. In: Comissão Pastoral da Terra, A Luta pela Terra: a CPT 20 anos depois. São Paulo: Paulus, 1997.

6. MORAIS, J, F, REGIS - Os Bispos e a Política no Brasil. São Paulo: Editora Cortez/Editora Autores Associados, 1982.

7. PESSOA, JADIR DE MORAIS - A Revanche Camponesa. Goiânia: Editora Universidade Federal de Goiás, 1999.

8. POLETTO, IVO - A Terra e a Vida em Tempos Neoliberais. Uma releitura da história da CPT. In: Comissão Pastoral da Terra, A Luta pela Terra: a CPT 20 anos depois. São Paulo: Paulus, 1997.

9. POlETtO, IVO, CANUTO, ANTONIO - Nas Pegadas do Povo da Terra. 25 anos da Comissão Pastoral da Terra. São Paulo: Edições Loyola, 2002.

10. OLIVEIRA, ARIOVALDO U. - A Fronteira Amazônica MatoGrossense: Grilagem, Corrupção e Violência. São Paulo: Tese de Livre Docência. Dep. de Geografia, FFLCH. USP, 1997.

Geografia das lutas no campo. São Paulo: Contexto, 1988.

12. SADER, MARIA REGINA C. T. - Espaço e Luta no Bico do Papagaio. São Paulo: Tese de Doutorado. Departamento de Geografia, Faculdade de Filosofia, Letras e Ciências Humanas da Universidade de São Paulo, 1986. 